\title{
Modele culturale de standardizare lingvistică $\breve{a}^{\dagger}$
}

\author{
Dirk Geeraerts* \\ Unitatea de Cercetare Lingvistică, Universitatea Catolică din Leuven, Blijde-Inkomststraat 21, PO Box 03308, B-3000 Lenven, Belgia
}

\section{Despre articol \\ Istoric:}

Primit 9 februarie 2015

Acceptat 18 septembrie 2015

Publicat 12 februarie 2016

Cuvinte-cheie:

modele culturale

lingvistică cognitivă

psiholingvistică

\begin{abstract}
Rezumat
În acord cu tendințele din teoria culturală (vezi Burke et al., 2000), lingvistica cognitivă evidențiază faptul că noi înțelegem realitatea socială prin prisma unor modele, „modele culturale” sau "teorii naive (populare)”, și, de la Holland \& Quinn (1987) la Lakoff (1996) și Palmer (1998) pînă la Dirven et al. (2001a, 2001b), specialiștii în lingvistică cognitivă au demonstrat că instrumentarul tehnic al lingvisticii cognitive poate fi utilizat pentru a arăta că perspectivele noastre asupra realității sociale sînt modelate pe baza unor de tipare de gîndire. Însă, dacă limba este o realitate socială și culturală, ce modele ne formează concepția despre limbă? Mai exact, care sînt modelele care formează modul nostru de a gîndi despre limbă ca fenomen social? Care sînt paradigmele pe care le folosim pentru a gîndi despre limbă, nu neapărat ca structură lingvistică (aşa cum se observă în Reddy 1979), ci ca variație lingvistică, adică modelele despre felul în care varietățile lingvistice sînt răspîndite într-o comunitate lingvistică și maniera prin care această distribuție ar trebui evaluată?

Scopul lucrării de față este de a discuta existența a două modele de bază: cel raționalist și cel romantic. Voi cartografia modalitățile prin care aceste două modele interacționează, voi descrie evoluția lor în curgerea timpului și voi explora modul în care ele pot fi întrebuințate pentru a analiza variația lingvistică actuală.
\end{abstract}

\section{Modele culturale şi variaţie lingvistică}

Pentru a înscrie lucrarea într-un context mai cuprinzător, se impun două considerații preliminare. Mai întîi, analiza este un produs secundar al interesului principal de a cerceta, prin recurs la metode empirice, variația și schimbarea lingvistică. Activitatea pe care am depus-o în ultimul deceniu împreună cu membrii grupului meu de cercetare s-a axat mai cu seamă asupra diverselor aspecte ale schimbării și variației lingvistice: semantica diacronică (Geeraerts, 1997), raportul dintre variația semantică și cea lexicală (Geeraerts et al., 1994) și variația lexicală în limbile pluricentrice precum olandeza (Geeraerts et al., 1999). În această ultimă direcție de cercetare, ne-am interesat mai ales de dezvoltarea unor tehnici cantitative de măsurare a variației lingvistice și a proceselor de standardizare lexicală (vezi infra, \$4).

Există, aşadar, două maniere în care lucrarea de față, mai mult sau mai puţin eseistică, poate fi legată de cercetările mai riguroase de tip descriptiv și metodologic ale principalei mele arii de interes. În primul rînd, cercetarea uzului lingvistic trebuie completată cu o cercetare a felului în care vorbitorii unei limbi se raportează la o situație dată. Modelele culturale pe care le voi discuta reflectă, într-un anumit sens, atitudini lingvistice de bază, iar o interpretare adecvată a variaţiei lingvistice ar trebui, în mod evident, să țină seama atît de atitudinile vorbitorilor față de limbă cît și de comportamentul lor lingvistic, ca atare.

Totodată, se cuvine arătat că ambele perspective (cea comportamentală și cea atitudinală) intră în sfera preocupărilor de lingvistică cognitivă. În timp ce perspectiva atitudinală se inspiră din analiza, cu mijloacele lingvisticii cognitive, a modelelor culturale și a teoriilor naive, perspectiva comportamentală se situează în continuitatea interesului arătat de lingvistica cognitivă variației lexico-semantice, așa cum

\footnotetext{
${ }^{\dagger}$ Lucrarea a fost publicată inițial în volumul Cognitive Models in Language and Thought. Ideology, Metaphors and Meanings, editat de René Dirven, Roslyn Frank și Martin Pütz, Mouton de Gruyter, Berlin/New York, 2003, p. 25-68, CrossRef.

*Adresă de corespondență: dirk.geeraerts@arts.kuleuven.be.
} 
Dirk Geeraerts

este ea ilustrată de teoria prototipurilor. La baza publicațiilor menționate anterior stă o direcție logică de dezvoltare, dinspre teoria semasiologică a prototipurilor (Geeraerts, 1997) spre un model de variație lexicală care înglobează variația onomasiologică (Geeraerts et al., 1994), care, la rîndul ei, se extinde spre o investigație a factorilor de variație sociolectali și dialectali „externi” (Geeraerts et al., 1999).

Ca remarcă preliminară secundă, ne putem întreba ce diferență există între un „model cultural” și o ideologie. În lingvistica cognitivă s-a încetățenit ideea că modelele culturale ce articulează judecata și argumentarea sînt în oarecare măsură esențe idealizate (a se vedea, de pildă, conceptul de model cognitiv idealizat introdus de Lakoff, 1987). Fenomenele și situațiile concrete diferă în mai mică sau în mai mare măsură de modelele considerate ca puncte de referință cognitivă și chiar modelele ca atare sînt într-o anumită măsură abstracte, generale şi întrucîtva simpliste, tocmai din cauză că recurgem la ele pentru a da sens unor fenomene intrinsec mai complicate.

În raport cu fenomenele sociale, modelele culturale sînt nu numai esențe idealizate, ci și constructe ideologice. Modelele culturale pot fi ideologii sub două aspecte: fie atunci cînd caracterul lor idealizat este uitat (cînd este neglijată deosebirea dintre modelul abstract și circumstanțele reale), fie atunci cînd ele sînt folosite mai degrabă prescriptiv și normativ decît descriptiv (cînd sînt întrebuințate ca modele menite să explice nu cum sînt lucrurile, ci cum ar trebui ele să fie). În cel de-al doilea caz, ideologia este ghidul de bază al acțiunii sociale, sistemul comun de idei prin care este interpretată realitatea socială, indiferent de evaluarea cercetătorului. În primul caz, ideologia este întotdeauna un camuflaj, o aparență, o reprezentare deliberat deformată a realului, aşa că descrierea acestor ideologii se cuvine, cu necesitate, realizată critic.

Distincția este, de bună seamă, cunoscută în cercetarea ideologiei și există o literatură științifică bogată prin care este probată legătura dintre limbă și ideologie. Pot fi amintite două direcții fundamentale (și întrucîtva întrepătrunse): avem, pe de o parte, toate formele de analiză critică a discursului, așa cum sînt ele ilustrate de van Dijk (1998), Wodak \& Meyer (2001) sau Blommaert \& Bulcaen (1997), și, pe de altă parte, direcția „ideologiilor de limbaj”, reprezentată de Joseph \& Taylor (1990), Woolard et al. (1998) şi Schiffman (1996). Conform primei orientări, orice text este analizat critic în funcție de rolul avut pe scena socială a puterii, adică în privința modului de a oglindi și de a reacționa față de raporturile sociale deja existente. Cealaltă orientare este concentrată asupra felului în care credințele legate de variația lingvistică şi de anumite varietăţi de limbă se manifestă în chip explicit (ca în cazul politicilor lingvistice) sau implicit (ca în practicile educative) și asupra interacțiunilor dintre credințe în raport cu identitatea de grup, cu dezvoltarea economică, cu mobilitatea socială și cu organizarea politică.

În paginile care urmează, nu voi adopta un demers critic, ci o concepție mai degrabă neutră și descriptivă asupra modelelor culturale de natură lingvistică. În loc de a analiza critic anumite practici și politici considerate sub aspect ideologic, voi încerca să explorez fundamentele și dezvoltarea istorică a unor modele culturale concurente prin care se articulează respectivele practici și politici și le voi examina critic.

\section{Modelul raționalist și modelul romantic}

În această secțiune, voi prezenta cele două modele culturale de bază pe care consider că trebuie să le distingem dacă vrem să înțelegem logica dezbaterilor privind standardizarea: modelul raționalist şi modelul romantic. Le voi prezenta contrastiv, arătînd că fiecare se contrapune în mare parte celuilalt și că ele se afla într-un raport dialectic. Cu toate acestea, compararea celor două modele nu este realizată exhaustiv. În secțiunea următoare, demersul comparativ va fi extins și va conduce la identificarea a două prefaceri istorice ale modelelor de bază, sub forma modelelor naționalist și postmodernist.

\subsection{Modelul raționalist}

Ce caracteristici sînt atribuite, așadar, în mod ideal (și, probabil, ideologic) limbilor literare ${ }^{1}$ ? Probabil că trăsătura lor cea mai evidentă este generalitatea. Spre deosebire de dialecte și de limbaje, limbile literare sînt generale sub trei aspecte.

\footnotetext{
${ }^{1}$ În lingvistica românească, pentru noțiunea de limbă standard, de care se servește autorul articolului, s-a impus conceptul de limbă literară, la care recurgem în cele ce urmează (n.tr.).
} 
Din punct de vedere geografic, ele sînt generale în sensul că depăşesc ariile de recurs la dialect. Mai apoi, limbile literare sînt generale sub aspect social întrucît ele constituie idiomul comun, care nu aparţine nici unui grup social, aflîndu-se la dispoziția masei de vorbitori. În sfîrșit, ele sînt universale din punct de vedere tematic, în sensul că sînt adaptate pentru a face față solicitărilor oricărui domeniu semantic și oricărei funcții lingvistice. Domeniile avansate de activitate (precum știința și cultura înaltă) nu se înscriu în raza locală a dialectelor.

Datorită naturii lor generale, limbile literare prezintă încă două atribute. În primul rînd, se presupune că ele formează un mediu neutru, avînd funcție de mediere, în sensul filosofic de „mediere”. De fapt, limbile literare transcend deosebirile sociale și asigură libera comunicare între toți indivizii unui popor.

Considerate din acest unghi, limbile literare sînt mijloace de participare și de emancipare. Grație neutralității și generalității lor funcționale, limbile literare constituie cheia către universul educației și culturii înalte, iar acestea sînt domeniile funcționale par excellence de întrebuințare a limbii literare (sau, inversînd perspectiva, acestea sînt domeniile funcționale la care cineva nu are acces doar prin simpla cunoaștere a unui dialect). Poate și mai importantă este supoziţia că limbile literare favorizează participarea politică. Posibilitatea de a comunica nestingherit este o caracteristică a organizării politice democratice, în sensul idealului de 'herrschaftsfreie Kommunikation' prezentat de Jürgen Habermas. Cînd standardizarea lingvistică înlesnește înțelegerea reciprocă și libera comunicare, acesta este un factor de emancipare politică, dar și un factor de emancipare socială, întrucît contribuie la răspîndirea culturii și educației. Prin contrast, dacă cineva crede în efectele benefice ale standardizării, dialectele apar ca relicte ale unui sistem social și politic obscurantist care se opune democrației și emancipării.

În contextul demitizării ideologice postmoderne, o asemenea viziune pozitivă asupra standardizării apare, fără îndoială, ca suspectă, dar pentru mine e de importanță crucială să argumentez că, cel puțin la momentul apariției sale (Iluminismul secolului al XVIII-lea), elogiul închinat standardizării era autentic. Să urmărim, de exemplu, cîteva fragmente din raportatele Convenției revoluționare din Franța. Barère (1975) face următoarele aprecieri:

(1) Citoyens, la langue d'un peuple libre doit être une et la même pour tous. (1975, p. 297)

[Cetățeni, limba oamenilor liberi trebuie să fie una și aceeași pentru toți.]

(2) Les lumières portées à grands frais aux extrémités de la France s'éteignent en y arrivant, puisque les lois n'y sont pas entendues. (1975, p. 295)

[Luminile purtate cu mari eforturi în colțurile îndepărtate ale Franței se sting cînd ajung acolo pentru că legile nu sînt înțelese.]

(3) Laisser les citoyens dans l'ignorance de la langue nationale, c'est trahir la patrie; c'est laisser le torrent des lumières empoisonné ou obstrué dans son cours; c'est méconnaître les bienfaits de l'imprimerie, car chaque imprimeur est un instituteur public de langue et de législation. (1975, p. 296-297)

[Să lăsăm cetățenii ignoranți în privința limbii naţionale înseamnă să ne trădăm patria, înseamnă să lăsăm șuvoiul luminilor să fie otrăvit și îndiguit în calea sa, înseamnă să nu respectăm binefacerile tiparului, fiindcă toți tipografii sînt dascăli publici ai limbii și ai legii.]

(4) Citoyens, les tyrans coalisés on dit: l'ignorance fut toujours notre auxiliaire le plus puissant; maintenons l'ignorance; elle fait les fanatiques, elle multiplie les contre-révolutionnaires; faisons rétrograder les Français vers la barbarie: servons-nous des peuples mal instruits ou de ceux qui parlent un idiome différent de celui de l'instruction publique. (1975, p. 291)

[Cetățeni, tiranii laolaltă au zis: ignoranța a fost mereu ajutorul nostru cel mai puternic; să menținem, deci, ignoranța pentru că ea dă naștere fanaticilor și înmulțește contrarevoluționarii. Să ne asigurăm că Franța cade în barbarie și să ne folosim de oamenii slab educați și de cei ce vorbesc o limbă diferită de cea a instrucției publice.]

(5) Les habitants des campagnes n'entendent que le bas-breton; c'est avec cet instrument barbare de leurs penseés superstitieuses que les prêtres et les intrigants les tiennent sous leur empire, dirigent leurs 
consciences et empêchent les citoyens de connaître les lois et d'aimer la République. Vos travaux leur sont inconnus, vos efforts pour leur affranchissement sont ignorés. (1975, p. 292-293)

[Țăranii vorbesc doar bretona și, cu această unealtă barbară a gîndirii lor superstițioase, preoții și intriganții reușesc să îi țină pe oameni subjugați, să le controleze conștiințele și să îi împiedice să cunoască legile Republicii. Lucrările voastre le sînt necunoscute, eforturile voastre de dezrobire rămîn neștiute.]

Trăsăturile limbilor literare (generalitatea și neutralitatea comunicativă, efectele emancipative și participative, opoziția față de obscurantism) pot fi identificate cu ușurință în aceste fragmente. Primul fragment, (1), subliniază generalitatea și uniformitatea limbii literare. Fragmentele (2) și (3) reliefează funcția de emancipare a limbii literare: cetățenii care știu doar dialectul propriu nu vor înțelege legile Republicii (fiind, desigur, presupus că acestea au efect eliberator) și nici nu vor fi în stare să profite de beneficiile tiparului, în general vorbind. Secvențele (4) și (5) asociază în mod clar dialectele cu obscurantismul contra-revoluționar, sugerîndu-se că preoții și „tiranii” mențin în chip deliberat ignoranţa prin piedicile puse oamenilor de a-și însuși limba literară.

O concepție asemănătoare poate fi descoperită în următoarele fragmente, preluate din Grégoire (1975), care prezintă Convenției un întreg proiect educativ „de a aboli dialectele și de a generaliza folosirea limbii franceze”. (În concepția sa, 'dialect' include nu doar dialectele limbii franceze, ci și celelalte limbi vorbite pe teritoriul Franței, precum germana, în Alsacia, flamanda, în zona de nord și bretona, în Bretania).

(6) Mais au moins on peut uniformer le langage d'une grande nation, de manière que tous les citoyens qui la composent puissent sans obstacle se communiquer leurs pensées. Cette entreprise, qui ne fut pleinement exécutée chez aucun peuple, est digne du peuple français, qui centralise toutes les branches de l'organisation sociale et qui doit être jaloux de consacrer au plutôt, dans une République une et indivisible, l'usage unique et invariable de la langue et de la liberté. (1975, p. 302)

[Limbajul unei mari națiuni poate fi uniformizat într-atît încît toți cetățenii să-și poată comunica gîndurile fără nici o dificultate. Această întreprindere, pe care nici un popor nu a realizat-o încă pe deplin, este demnă de poporul francez, în care se reunesc toate ramurile organizării sociale și care trebuie să aibă ardoarea de a beneficia cît mai curînd, într-o Republică unitară și indivizibilă, de foloasele unice și invariabile ale limbii și ale libertăţii.]

(7) 'Il y a dans notre langue, disait un royaliste, une hiérarchie de style, parce que les mots sont classés comme les sujets dans une monarchie'. Cet aveu est un trait de lumière pour quiconque réfléchit. En appliquant l'inégalité des styles à celle des conditions, on peut tirer des conséquences qui prouvent l'importance de mon projet dans une démocratie. (1975, p. 316)

[În limba noastră, afirma un regalist, există o ierarhie a stilurilor, deoarece cuvintele sînt ordonate precum supușii unei monarhii. Această mărturie e ca o rază de lumină pentru orice cugetător. Prin aplicarea inegalităţii stilurilor la inegalitatea condiţiilor de viaţă, se pot trage concluzii care dovedesc importanța proiectului meu (de standardizare lingvistică printr-o politică de educație lingvistică n.a.) într-o democrație.]

(8) Tous les membres du souverain sont admissibles à toutes les places; il est à désirer que tous puissent successivement les remplir, et retourner à leurs professions agricoles ou mécaniques. Cet état de choses nous présente l'alternative suivante: si ces places sont occupées par des hommes incapables de s'énoncer, d'écrire dans la langue nationale, les droits des citoyens seront-ils bien garantis par des actes dont la rédaction présentera l'impropriété des termes, l'imprécision des idées, en un mot tous les symptômes de l'ignorance? Si au contraire cette ignorance exclut des places, bientôt renaîtra cette aristocratie qui jadis employait le patois pour montrer son affabilité protectrice à ceux qu'on appelait insolemment les petites gens. [...] Ainsi l'ignorance de la langue compromettrait le bonheur social ou détruirait l'égalité. (1975, p. 303)

[Toți membrii poporului suveran pot fi aleși în toate oficiile. Este de dorit ca toți să poată ocupa succesiv aceste poziții și mai apoi să se întoarcă la îndeletnicirile lor agricole și industriale. Această 
stare de fapt ne apare ca avînd următoarea alternativă. Dacă aceste poziții sînt ocupate de oameni incapabili să se exprime și să scrie în limba națională, vor mai fi oare drepturile cetățenești garantate prin acte în a căror redactare se observă termeni improprii, imprecizie a ideilor, într-un cuvînt, toate simptomele neștiinței? Dacă, dimpotrivă, ignoranța îi împiedică pe oameni să ocupe oficiile, în curînd va renaște aristocrația care în trecut se folosea de dialect pentru a-și manifesta afabilitatea protectoare față de cei considerați cu insolență drept 'oameni simpli'. [...]. Prin urmare, necunoașterea limbii ar compromite binele social și ar distruge egalitatea.]

Fragmentul (6) evidențiază generalitatea comunicativă a limbii literare. O limbă unitară nu numai că simbolizează unitatea unei națiuni, dar le şi asigură cetățenilor libertatea de comunicare a gîndurilor. Fragmentul (7) unește în mod simbolic absența standardizării cu situația de dinainte de revoluție, adică faptul că existența unor varietăți de limbă organizate ierharhic oglindește ordinea ierarhică a societății. Fragmentul (8) prezintă în termeni sugestivi funcția de emancipare politică a standardizării. Idealul egalității presupune ca fiecare cetățean să poată participa la guvernarea națiunii; de fapt, ideal ar fi ca toți cetățenii să ocupe succesiv funcții politice, după care să revină în mediul lor profesional. Totuşi, pentru a îndeplini aceste îndatoriri publice, este necesară o bună cunoaștere a limbii comune. Necunoaşterea limbii n-ar trebui să-i împiedice pe oameni să acceadă în funcții. De aceea, este nevoie de efort educativ pentru a asigura standardizarea. Grégoire este un adept înfocat al „S, Scolii publice” ca forță de literarizare.

În $\$ 3$ voi descrie prefacerile prin care a trecut idealul raţional şi iluminist al standardizării în ultimele două secole. Cu toate acestea, chiar şi ipostaza transformată presupune o evaluare pozitivă a standardizării, printr-una sau alta dintre trăsăturile menționate, neutralitatea funcțională a medierii comunicative și efectele emancipative și participative susținute de un sistem de educaţie centrat pe răspîndirea limbii literare.

\subsection{Modelul romantic}

Concepția romantică despre standardizare poate fi uşor definită în contrast cu cele două trăsături dominante ale modelului raționalist. Mai întîi, în antiteză cu țelurile emancipative și participative ale viziunii iluministe, viziunea romantică va încerca să atragă atenția asupra faptului că limbile literare sînt instrumente ale opresiunii și excluderii. În acest punct, analiza standardizării ia, desigur, forma criticii ideologice şi va căuta să arate că idealurile iluministe nu sînt adesea împlinite şi că, de fapt, procesele de standardizare ating în mod obișnuit reversul a ceea ce ele năzuiesc să atingă. Deși termenul nu este des folosit, acest tip de discurs critic se reduce la demonstrația că standardizarea lingvistică ilustrează ceea ce Horkheimer \& Adorno (1947) au considerat a fi 'Dialektik der Aufklärung', adică dialectica (negativă a) Iluminismului. Horkheimer și Adorno arată că pozițiile raţionaliste au tendința de a conduce către contrariile lor dialectice (în sensul că, spre exemplu, stăpînirea omului asupra naturii, prin tehnică, poate conduce către distrugerea lumii naturale).

Dacă reluăm cele trei tipuri de generalitate ce caracterizează limbile literare, e uşor de observat că materializarea idealului are tendința de a contrazice idealul, iar acesta este obiectul dialecticii Iluminismului (Dialektik der Aufklärung).

În primul rînd, se presupune că limbile literare sînt neutre în plan geografic, deși, în realitate, procesele de standardizare își au adesea originea într-o anumită regiune dominantă sub aspect economic, cultural și/sau politic. Pentru vorbitorii din celelalte regiuni, limba literară nu este un mediu neutru, ci un mijloc de afirmare a supremației regiunii dominante. De exemplu, limba franceză literară nu este o limbă imparțială apărută din neant, ci este limba vorbită de clasele medii și superioare din Paris și Ile-de-France și este asociată cu rolul pe care regiunea centrală îl joacă încă din epoca medievală.

În al doilea rînd, se presupune că limbile literare sînt generic funcționale, dar, în practică, ele sînt în mod obișnuit folosite în contexte de tip cultural, educativ, științific, administrativ și politic sau cel puțin în acele împrejurări în care o comunitate lingvistică nu a atins încă un standard. Prin contrast, varietăţile nestandardizate pot căpăta în mod firesc accente noi. Pe de o parte, dacă limba literară este limba vieții publice, varietățile nestandardizate vor fi mai degrabă asociate cu intimitatea și familiaritatea decît cu sfera 
publică. Pe de altă parte, dacă limba literară funcționează în contexte de tip intelectual (educația și știința), varietățile nestandardizate vor fi învestite cu valori afective. Pentru vorbitorii unui dialect, acesta este limba stărilor afective, a spontaneității și naturaleții, spre deosebire de limba oficială în care se realizează educația. În mod ironic, generalitatea funcțională a limbii literare dă naștere unei specializări funcționale prin care sfera publică e separată de cea privată, cea afectivă, de cea intelectuală.

În al treilea rînd, se presupune că limbile literare sînt neutre în plan social, dar, în realitate, ele sînt de fapt limbi ale elitelor. Legătura unei elite economice, culturale sau politice cu limba literară este, în fond, un efect secundar al generalităţii funcționale a limbilor literare. Dacă limbile literare sînt îndeobște folosite în contexte de tip cultural, educativ, științific, administrativ și politic, atunci vorbitorii aflați în astfel de contexte vor învăța mai ușor limba literară și o vor adopta ca limbă primă decît vorbitorii care nu cunosc aceste categorii de uz. Prin urmare, cei excluși vor percepe performanța lingvistică superioară a elitei ca factor ce contribuie la excluderea socială. În concepția lui Grégoire, cunoașterea limbii literare favorizează mobilitatea socială, dar, dimpotrivă, răspîndirea socială reală a uzului limbii literare poate preface limba literară într-un instrument de discriminare.

Altfel spus, putem observa că presupusa generalitate a limbilor literare poate lua forma unor serii de specializări. Procesul de standardizare își are originea în limba anumitor regiuni, anumitor grupuri de vorbitori și anumitor utilizări și domenii de activitate, iar acest fapt inevitabil poate răsturna idealul unei standardizări benefice. Cînd acest lucru se întîmplă, idealul inițial poate fi denunțat ca pretext ideologic.

Nici nu mai trebuie spus că această răsturnare dialectică poate afecta și sistemul de educaţie. Dacă limba literară este înțeleasă ca instrument de oprimare, discriminare și excludere socială, sistemul de educație va fi de asemenea respins pe motiv că își aduce contribuția la activarea mecanismelor de excludere socială. În loc ca școala să fie considerată o instituție ce promovează cunoașterea limbii comune (și cunoașterea, în general), pentru a crea posibilități de mobilitate socială, se va arăta că sistemul de educație bazat pe ceva mai mult decît pe cunoașterea limbii îi avantajează pe vorbitorii a căror condiție socială le asigură o mai bună stăpînire a limbii literare, iar acest avantaj nu împiedică, ci întreține inegalitatea socială.

De ce este numită „,model romantic” această răsturnare critică a aprecierii faţă de limba literară? De ce să nu fie numită 'model realist', 'model critic' sau 'model anti-ideologic'? Motivul este că această atitudine critică este adesea (deși nu în mod necesar) însoțită de o a doua trăsătură care poate fi pusă în opoziție cu cea de-a doua caracteristică a modelului raționalist. Cu alte cuvinte, am constatat doar punerea sub semnul întrebării a rostului emancipativ, participativ al modelului iluminist. Dar la ce se referă cea de-a doua trăsătură? Ce ar fi de spus despre aspectele comunicative ale modelului raționalist?

Se poate identifica un veritabil model 'romantic' al variației lingvistice cînd atitudinii critice față de standardele oficiale i se adaugă viziunea potrivit căreia limba este mai degrabă un mijloc de expresie decît de comunicare. Potrivit perspectivei iluministe, limbile sînt mijloace de comunicare, iar limba literară este un instrument superior de comunicare deoarece ea este funcțional generală și social neutră.

Conform perspectivei romantice, limbile sînt mai degrabă expresive decît comunicative. Ele sînt expresii ale unei identități și, ca atare, ele întruchipează o anumită concepție despre lume, o viziune asupra lumii, „Weltanschauung”, după cum afirmă Herder. Legătura dintre această faimoasă concepție romantică asupra relației dintre limbă și gîndire și dezbaterea legată de standardizare devine limpede. Din moment ce limbile sau varietățile lingvistice reflectă o anumită identitate, atunci preferința față de o limbă sau de o anumită varietate lingvistică în raport cu o alta presupune că identitatea specifică a unui anumit grup de indivizi este neglijată sau negată. A nu recunoaște limba înseamnă a nu-i recunoaște pe vorbitorii ei. Dacă anumite varietăți de limbă capătă rol secundar datorită existenței unei limbi literare, atunci vorbitorilor respectivelor varietăți lingvistice li se neagă un drept fundamental, dreptul de a se exprima în propriul idiom — de fapt, singura limbă care le justifică identitatea individuală, potrivit concepției romantice asupra raportului dintre limbă și identitate.

Un corelat al acestei poziții este evaluarea pozitivă a diversității. În timp ce perspectiva raționalistă prețuiește uniformitatea lingvistică considerată ca expresie a simbolică a unei comunități libere și deschise, în care toți cetățenii au drept egal de a se exprima, perspectiva romantică apreciază diversitatea ca formă 
de recunoaștere a respectului fundamental față de diferite alte identități.

Pe scurt, viziunea romantică asupra variației și standardizării lingvistice opune concepției iluministe privind limba ca mijloc de comunicare, perspectiva limbii ca expresie a identității individuale. Idealului raționalist emancipativ și participativ i se opune o concepție critică asupra standardizării, considerată ca mecanism de discriminare și excludere, iar aprecierii pozitive privind educaţia ca mijloc de răspîndire a cunoașterii limbii i se opune neîncrederea fundamentală că școala este parte a unui sistem de întreținere a inegalității sociale.

Pentru a ilustra acest model, nu voi recurge la un exemplu istoric, aşa cum am procedat în cazul modelului raționalist, ci voi examina succint dezbaterea actuală privind genocidul lingvistic și statutul internaţional al limbii engleze. În această formă de variaţie interlingvistică, limba engleză înlocuiește limba literară a variației intralingvistice, iar limbile minoritare amenințate cu dispariția înlocuiesc varietățile non-standard. Toate obiecțiile pe care perspectiva romantică le-ar ridica împotriva unei variante literare, s-ar răsfrînge și asupra dominației internaționale a limbii engleze. Să luăm, pentru ilustrare, următoarele fragmente dintr-un rezumat realizat de Skutnabb-Kangas (2000). Rezumatul poate fi găsit și pe pagina personală de internet a autoarei.

(9) Indigenous peoples and minorities are the main bearers of linguistic and cultural diversity in the world-over $80 \%$ of the world's languages exist in one country only and the median language has no more than 5,000 speakers. Some of the direct main agents of linguistic (and cultural) genocide today are parts of what we call the consciousness industry: formal educational systems and the mass media. [...] The book shows that the education of most minorities and indigenous peoples in the world is organized in ways which both counteract sound scientific principles and lead to the disappearance of linguistic and cultural diversity. [...] Schools are every day committing linguistic genocide. [...] They also do it by forcibly moving children from one group (indigenous or minority) to another group (the dominant group) through linguistic and cultural forced assimilation in schools. [...] This inevitably includes a consideration of power relations. The book shows how the formal educational systems participate in maintaining and reproducing unequal power relations, here especially between linguistic minorities and others, but also more generally, and how the ways of doing this have changed and are constantly changing, and how control and domination are resisted and alternatives are constantly created and negotiated, managed and controlled, and recreated. The deficiency-based models that are used in most minority education invalidate the linguistic and cultural capital of minority children and their parents and communities. They make the resources of dominated groups seem handicaps or deficiencies, instead of valued and validated non-material resources, or they render them invisible and therefore not possible to convert into material resources and positions of structural power. This happens just as much in global international relations and the Mcdonaldization of the world as it happens in ESL classrooms.

[Populațiile indigene și minoritățile sînt principalii reprezentanți ai diversității lingvistice și culturale mondiale-peste $80 \%$ din limbile lumii sînt vorbite doar într-o singură țară și, în medie, o limbă nu are mai mult de 5.000 de vorbitori. Unii dintre agenții direcți și principali ai genocidului lingvistic (și cultural) contemporan fac parte din ceea ce noi considerăm a fi industria conștiinței: sistemele de educație formală și mijloacele de informare în masă. (...) Volumul dezvăluie că educația celor mai multe minorități și populații autohtone din lume este organizată în modalități care contrazic principiile știinţifice sănătoase și grăbesc dispariția diversităţii lingvistice şi culturale. (...) În fiecare zi, școlile comit genocid lingvistic. (...) Acest lucru se realizează prin mutarea forțată a copiilor dintrun grup (indigen sau minoritar) într-altul (grup dominant) și prin asimilare forțată de achiziții lingvistice și culturale petrecută în școli. (...) Acest fapt determină, în mod inevitabil, o reconsiderare a raporturilor de putere. Volumul arată cum anume participă sistemele de educație formală la păstrarea și perpetuarea relațiilor inegale de putere, în special între minorităţile lingvistice și ceilalți, dar și în general, cum anume aceste raporturi se schimbă permanent și cum anume rezistența la dominație și control generează alternative care se negociază, se gestionează, se valorifică și se recreează. Mo- 
delele bazate pe deficiență folosite în educaţia minorităţilor anulează capitalul cultural și lingvistic al copiilor minoritari, al părinților acestora și al comunităților lor. Prin aceste modele, resursele grupurilor dominate sînt considerate ca handicapuri sau ca deficiențe, și nu ca resurse imateriale valoroase și certificate, sau sînt considerate ca neglijabile și, de aceea, imposibil de preschimbat în resurse materiale și poziții de putere structurală. Acest lucru se petrece aproape la fel de mult atît în relațiile internaționale globale și în McDonaldizarea lumii, cît și în clasele în care limba engleză se predă ca limbă secundă (ESL)].

Indiferent dacă Skutnabb-Kangas are sau nu dreptate, elementele concepției romantice sînt în mod evident prezente în expunerea autoarei. În primul rînd, dispariţia limbilor și dispariția culturilor sînt puse în raport de echivalență. Chiar conceptul de 'genocid lingvistic' evocă exterminarea unei întregi populații (sau culturi) și a limbii acesteia. În contrast cu acest proces de asimilare forţată și dispariție, culturile diferite trebuie recunoscute ca fundamental egale, iar diversitatea ar trebui prețuită ca scop în sine. În al doilea rînd, răspîndirea internaţională a limbii engleze nu determină emanciparea și participarea, ci servește mai degrabă oprimării pe plan internațional, mai ales din partea companiilor multinaționale. În al treilea rînd, în text sînt exprimate îndoieli fățișe cu privire la rolul pe care îl au școlile în acest joc de putere lingvistică și culturală.

\subsection{Modelele raționalist și romantic și originea limbajului}

În paginile anterioare, nu numai că am schițat cele două modele de standardizare, raționalist și romantic, dar am și arătat că ele se înscriu într-o strînsă relație specifică. Pe lîngă faptul că unul se opune celuilalt, între modele există un raport dialectic, în sensul că mecanismele actuale de standardizare par prinse într-o 'dialectică a Iluminismului' negativă, în cursul căreia idealurile raționaliste pozitive tind să fie subminate spre a face loc atitudinii critice romantice asupra standardizării. Totuşi, acest raport dialectic, sintetizat în Tabela 1, nu epuizează legăturile dintre cele două modele de bază.

\begin{tabular}{|c|c|c|}
\hline & MODELUL RAȚIONALIST & MODELUL ROMANTIC \\
\hline $\begin{array}{l}\text { baza lingvistico- } \\
\text { filosofică: }\end{array}$ & limba ca mijloc de comunicare & limba ca mijloc de expresie \\
\hline $\begin{array}{l}\text { concepția asupra } \\
\text { standardizării: }\end{array}$ & $\begin{array}{l}\text { ideal democratic: limba literară } \\
\text { considerată ca mijloc neutru de } \\
\text { participare socială }\end{array}$ & $\begin{array}{l}\text { atitudine critică anti-ideologică: } \\
\text { limba literară considerată ca mijloc } \\
\text { de excludere socială }\end{array}$ \\
\hline $\begin{array}{l}\text { concepția asupra variației } \\
\text { lingvistice: }\end{array}$ & $\begin{array}{l}\text { variația lingvistică considerată } \\
\text { ca piedică împotriva } \\
\text { emancipării }\end{array}$ & $\begin{array}{l}\text { variația lingvistică considerată ca } \\
\text { modalitate de exprimare a unor } \\
\text { identități diferite }\end{array}$ \\
\hline
\end{tabular}

Tabela 1: Modelele raționalist și romantic de standardizare

În această secțiune, voi explora pe scurt fundamentele lingvistice teoretice ale celor două modele, pornind de la întrebarea dacă fiecărui model îi corespunde o concepție proprie referitoare la limbaj. Voi argumenta că teoriile veacului al XVIII-lea referitoare la originea limbajului completează tabloul deja creionat. Am sugerat deja că modelul romantic și cel raționalist se deosebesc în privința perspectivei lor teoretice asupra limbii, în sensul că primul impune o perspectivă expresivă asupra limbii, iar cel de-al doilea, o perspectivă comunicativă. Distincția dintre cele două perspective poate fi și mai bine reliefată dacă se au în vedere unele din teoriile formulate în secolul al XVIII-lea cu privire la originea limbajului, adică în perioada în care pot fi descoperite izvoarele intelectuale ale celor două concepții, raționalistă și romantică, asupra variaţiei lingvistice.

Perspectiva expresivă asupra limbii poate fi ilustrată de viziunea lui Herder, în timp ce ideile lui Condillac pot reflecta perspectiva comunicativă. Viziunea lui Herder despre limbă ca expresie a unei viziuni interne asupra lumii dezvăluie calea urmată pentru a descrie geneza limbajului verbal: acesta ia naștere cînd 
omul exprimă felul în care înțelege lumea. În fragmentul următor, Herder arată cum omul, atunci cînd dă nume animalelor (în cazul de față, o oaie) identifică și exprimă o anumită însușire (în speță, behăitul oii):

(10) Weiss, sanft, wollicht—seine besonnen sich übende Seele sucht ein Merkmal,—das Schaaf blöcket! sie hat Merkmal gefunden. Der innere Sinn würket. Dies Blöcken, das ihr am stärksten Eindruck macht, das sich von allen andern Eigenschaften des Beschauens und Betastens losriss, hervorsprang, am tiefsten eindrang, bleibt ihr. Das Schaaf kommt wieder. Weiss, sanft, wollicht-sie sieht, tastet, besinnet sich, sucht Merkmal—es blöckt, und nun erkennet sies wieder! 'Ha! du bist das Blöckende!' fühlt sie innerlich, sie hat es Menschlich erkannt, da sies deutlich, das ist, mit einem Merkmal, erkennet und nennet (1978, p. 33)

[Albă, blîndă, lînoasă—spiritul caută cu sfială și tact o trăsătură distinctivă. Oaia behăie! Însușirea a fost descoperită. Simțul interior lucrează. Acest behăit care impresionează în cel mai înalt grad, care se desprinde de toate celelalte date vizuale sau tactile şi iese în evidență, rămîne definitoriu. Oaia se întoarce. Albă, blîndă, lînoasă—spiritul vede, simte, cugetă—iar oaia behăie și acum ea este recunoscută! „A! Tu ești cea care behăie!”, iar spiritul simte în sine că a recunoscut-o în mod omenesc, întrucît a identificat-o și i-a dat un nume, prin intermediul unei trăsături distinctive.]

Consideraţiile lui Herder pot fi puse în antiteză cu viziunea lui Condillac asupra originii limbajului. În timp ce Herder caută originea limbajului în nevoia cognitivă și epistemologică de a conferi identitate lucrurilor (sau, mai precis, de a le identifica într-o manieră specifică ce reflectă înțelegerea pe care omul o capătă despre lucrurile respective), Condillac face trimitere la o situație de natură comunicativă. În relatarea sa despre doi copii, el descrie cum anume strigătul de ajutor al unuia este recunoscut de celălalt și convenționalizat treptat ca semn specific.

(11) Celui qui souffroit parce qu’il étoit privé d'un objet que ses passions lui rendoient nécessaire, ne s'en tenoit pas à pousser des cris: il faisoit des efforts pout l'obtenir, il agitoit sa tête, ses bras, et toutes les parties de son corps. L'autre, ému à ce spectacle, fixoit les yeux sur le même objet; et [...] il souffroit de voir souffrir ce misérable. Dès ce moment il se sent intéressé à le soulager, et il obéit à cette impression, autant qu'il est en son pouvoir. Ainsi, par le seul instinct, ces hommes se demandoient et se prêtoient de secours [...]. Cependant les mêmes circonstances ne purent se répéter souvent, qu'ils n'accoutumassent enfin à attacher aux cris des passions et aux différentes actions du corps, des perceptions qui y étoient exprimées d'une manière si sensibles (1973, p. 194-195).

[Cel ce a suferit că i s-a luat un lucru pe care dorința îl reclamă ca necesar, nu s-a mulțumit doar cu ţipatul, ci s-a și agitat pentru a-l obține, mișcînd din cap, din brațe și din celelalte părți ale corpului. Celălalt, mișcat de acest spectacol, și-a fixat privirea asupra aceluiași obiect și (...) a simțit suferinţa nefericitului. Din acest moment, el simte pornirea de a-l compătimi și se supune acestui simțămînt cu toate puterile sale. Astfel, doar din instinct, oamenii se ajută unii pe alții (...). Dar astfel de situații nu se repetă de prea multe ori înainte ca oamenii să lege strigătele de emoție și diversele mișcări ale corpului de senzațiile pe care ei le exprimă atît de sugestiv.]

Deosebirea dintre Herder și Condillac constă și într-o deosebire de vederi asupra relației dintre limbă și cultură. Spre deosebire de Condillac, Herder nu crede că este posibilă explicarea originii limbajului uman pornindu-se de la strigătele emotive instinctuale. Înțelegerea precedă apariția limbajului uman conștient. În expunerea lui Condillac, înțelegerea sau 'reflecția' se dezvoltă treptat, prin folosirea semnelor într-o anumită situație de comunicare. Pentru Herder, nașterea limbajului presupune existența culturii umane, o cultură care să poată fi exprimată prin limbă. Din punctul de vedere al lui Condillac, cultura umană evoluează plecînd de la instincte, prin folosirea semnelor și dezvoltarea limbajului (a se vedea Sapir, 1907, pentru o perspectivă mai complexă).

Este, într-adevăr, corect să căutăm în secolul al XVIII-lea originile intelectuale ale modelelor noastre culturale de standardizare lingvistică, iar fragmentele (10) și (11) indică existența legăturilor cu teoretizările lingvistice din epocă. Această recunoaștere deschide calea spre studiul istoric mai cuprinzător al raporturilor dintre teoriile lingvistice și filosofia limbajului, pe de o parte, și politicile lingvistice, pe de 
altă parte. În ce măsură au influențat teoriile despre originea, natura și organizarea limbii maniera în care oamenii (şi guvernările) au conceput problemele referitoare la variaţie şi standardizare lingvistică? Literatura de specialitate oferă numeroase puncte de plecare, dar se axează mai ales asupra mecanismelor de standardizare și a politicilor lingvistice ale unei singure limbi sau națiuni. O posibilitate interesantă de a fructifica modelele culturale deja identificate ar fi de a observa dacă ele pot sau nu să stea la baza unei cercetari sintetice ale acestor legături istorice dintre teoria lingvistică și procesul de standardizare.

\section{Transformarea istorică a modelelor}

În această secțiune vor fi explorate momente diferite din evoluția celor două modele concurente, mai ales pentru a cartografia transformările petrecute în secolele al XIX-lea și al XX-lea. Mai întîi, voi arăta că modelul naționalist de standardizare, devenit foarte cunoscut în secolul al XIX-lea, constă dintr-un amestec aparte de elemente raționaliste și romantice. Mai apoi, voi avea în vedere felul în care conștiința noastră postmodernă afectează concurența dintre modelul raționalist și cel romantic. De altfel, e interesant de observat dacă modelele se manifestă sau nu în formă pură. Pînă și în exemplele din perioada Revoluției Franceze se constată prezența naționalismului patriotic. Dacă așa stau lucrurile, modelele prezentate în secțiunea precedentă vor trebui considerate ca puncte de referință analitice, ca 'modele cognitive idealizate', după cum se afirmă în lingvistica cognitivă.

\subsection{Secolul al XIX-lea și modelul naționalist}

Ambele modele, raționalist și romantic, fac dificilă situarea la un anumit nivel de relevanță. În forma sa extremă, modelul raționalist postulează existența unei limbi universale. Din moment ce forța activă care animă standardizarea presupune o maximizare a comunicării reciproce, atunci este recomandat recursul la o limbă universală care să depășească orice fel de variație lingvistică, în sensul că neutralizarea variației interlingvistice completează neutralizarea standardizării intralingvistice. Desigur, țelul adoptării unei limbi universale, ideale (esperanto, volapük și altele asemenea) este exact materializarea istorică a unei astfel de interpretări a perspectivei raționaliste.

Totuşi, în practica lingvistică, mișcările esperantiste au rămas marginale. Nivelul real la care s-au manifestat mecanismele de standardizare a rămas cel de jos, al unei națiuni. Încă de la constituirea modelului iluminist, logica acestui fapt este simplă (și poate fi, în fond, identificată în fragmentele din Barère şi Grégoire pe care le-am discutat): dacă standardizarea are în vedere participarea politică democratică, atunci, în mod evident, naţiunea, ca formă ideală de organizare politică, devine locus-ul procesului de standardizare și a eforturilor educative care îl susțin. Astfel, legătura intrinsecă dintre naționalism și perspectiva raţionalistă asupra standardizării nu mai apare ca surprinzătoare. Standardizarea lingvistică este, înainte de toate, un proces desfășurat în interiorul unei naţiuni, deoarece tocmai în interiorul națiunii se manifestă mecanismele de decizie politică la care standardizarea lingvistică ar trebui să contribuie. În acest punct, ar fi utilă o clarificare terminologică. 'Naționalismul' este ideologia politică prin care un stat, ca organizație politică, capătă legitimitate mai degrabă de la cetățenii săi decît prin tradiție, prin drept divin sau altcumva. Cu alte cuvinte, naționalismul pretinde că orice stat care se ridică la înălțimea acestei cerințe este o națiune. Raportul naționalist dintre indivizi și stat poate fi conceput în două maniere diferite. Conform unei distincții de uz comun în literatura de specialitate, putem deosebi naţionalismul civic de naționalismul identitar. Pe de o parte, naționalismul civic este concepția conform căreia legitimitatea unei naţiuni decurge din participarea activă a cetățenilor, printr-un sistem de reprezentare politică. Aceasta este viziunea liberală, raționalistă asupra naţionalismului. Pe de altă parte, naționalismul identitar este concepția conform căreia legitimitatea politică a unei naţiuni decurge din identitatea culturală a unui popor. Aceasta e viziunea romantică asupra naționalismului.

'Naționalism' se mai referă și la acțiunile și eforturile unui anumit grup de a deveni o națiune. Potrivit perspectivei naţionaliste, nu toate statele existente sînt în mod necesar națiuni, fie din cauză că nu au legitimitate democratică (punctul de vedere liberal), fie din pricină că nu recunosc identitatea culturală a anumitor grupuri (punctul de vedere romantic). În plan istoric, 'mișcările naționaliste' pot fi sau mișcări 
prin care se încearcă instituirea unei democrații liberale, sau mișcări prin care se revendică independența unui anumit grup ori a unei anumite regiuni. (Cu toate acestea, în uzul actual, tinde să predomine cea de-a doua accepție).

Raportul dintre limbă și naționalism pe care l-am înfățișat mai sus ține de ipostaza liberală, raționalistă a naţionalismului. Din moment ce legitimitatea unei națiuni decurge din participarea activă a cetățenilor ei, atunci maximizarea comunicării prin standardizare este un instrument de natură participativă. Dar, dacă ne îndreptăm atenția asupra naționalismului identitar, atunci naționalismul dezvoltă o legătură și mai puternică cu perspectiva romantică asupra limbii. În timp ce perspectiva raționalistă tinde către universalitate, perspectiva romantică tinde către individualitate. În forma sa extremă, concepția romantică asupra variaţiei lingvistice implică faptul că orice individ ar putea avea o limbă proprie. Așa cum perspectiva raționalistă tinde să maximizeze comunicativitatea, perspectiva romantică tinde să maximizeze variația individuală. În practică, o astfel de atitudine extremă nu se prea poate materializa. Cu excepția admirației romantice față de 'vocea unică a poetului' și alte asemenea aprecieri, viziunea romantică se referă mai degrabă la limbajul colectiv decît la cel individual. Identitatea exprimată prin limbă este cea a unei comunități, iar comunitatea devine națiune cînd dobîndește autonomie politică. De aici decurge binecunoscuta relație romantică dintre naționalism și limbă, așa cum este ea reflectată, printre alții, în Deprez \& Vos (1998). Potrivit modelului romantic, limba este, pe de o parte, corelată cu identitatea și, pe de altă parte, națiunile îşi dobîndesc legitimitatea din identitatea culturală a unui popor (dar acest lucru nu înseamnă că orice naționalism este și naționalism lingvistic; după cum se știe, identitatea poate rezulta și din acțiunea altor factori, precum religia și etnia.)

Considerat din două unghiuri diferite, naționalismul se raportează la limbă, iar această relație poate fi asociată cu cele două ipostaze de naţionalism distinse în teoria politică. Pe de o parte, naționalismul civic este concepția potrivit căreia legitimitatea națiunii decurge din participarea activă a cetățenilor, printrun sistem de reprezentare politică. Pe de altă parte, naționalismul identitar este concepția potrivit căreia legitimitatea politică a unei națiuni derivă din identitatea culturală a unui popor, iar limba este unul din factorii care stabilesc această identitate.

Solidaritatea dintre cele două forme de gîndire poate fi succinct ilustrată prin următoarele fragmente desprinse din Verlooy (1979). Avocat de limbă olandeză din Bruxelles, oraș aflat la vremea respectivă sub guvernare austriacă, Verlooy ia atitudine față de uzul crescînd al limbii franceze în viața publică și susține folosirea limbii sale materne, olandeza. În 1789, Verlooy a fost implicat în 'Brabantse Omwenteling' (Revoluția din Brabant, n.tr.), o insurgență ratată împotriva dominației austriece. Pamfletul său din 1788 poate fi citit ca resort intelectual al atitudinii sale naționaliste din anul ce avea să urmeze. Dar ce rol atribuie Verlooy limbii în gîndirea sa naționalistă?

(12) Het is zonder twyffel een goed voor eenigelyk wel ter tael en ter spraek te zyn, en zyne redens vaerdig en onbelemmert te voeren. Doch hier toe is een' zekere frankheyd noodig. Maer, gelyk by ons gezien en geplogen is, wanneer zullen wy frank zyn in die vremde tael? (1979, p. 58)

[Fără îndoială, e bine ca orice persoană să se poată exprima fluent şi să se poată angaja liberă în conversaţie. Dar pentru a dobîndi așa ceva e nevoie de naturalețe. Totuși, după cum se observă în cazul nostru, cum vom dobîndi această naturalețe într-o limbă străină?]

(13) Door ons frans schynen wy van die middelbare geleertheyd en borgerlyke wysheyd af geheel het gemeyn, onze bestgemoedde en weetgirige borgers, ambachtslieden, akkermans, en onze vrouwen: die ' $t$ frans teenemael niet, of ten minsten zoo verre niet en weten, dat-ze ' $t$ met vermaek of zonder moyelykheid konnen lezen: die daer door als als gedoemt schynen tot een' gezogte onwetendheyd. (1979, p. 49)

[Vorbind limba franceză, îi privăm de cunoașterea comună și de înțelepciunea civică pe toți oamenii de rînd, pe orășenii simpatici și curioși, pe meșteșugari, pe fermieri și pe femei, care nu cunosc limba franceză, sau cel puțin nu atît de bine încît să citească ușor și eficient, și, de aceea, par condamnaţi la ignoranță.] 
(14) Voor het vaderlanderschap eener natie is zeer dienstig zoo veel eygen en bezonder te hebben als mogelyk is (...) en zelfs hoe meer een' zaek uytwendigs heeft, gelyk de tael, dragten, toneelen, godsdienst, zeker plechten; hoe meer zy de gemoederen van 't volk zal aentrekken. [...] Waerom werken wy dan om zoo bekwamen band van vaderlanderschap, de moederlyke tael, te bannen? (1979, p. 59-60)

[Pentru a căpăta sentimentul identităţii naționale, e util să avem cît mai multe elemente comune și specifice cu putință, iar acestea vor intra cu atît mai repede în inimile oamenilor cu cît vor putea fi mai ușor observate, precum limba, vestimentația, teatrul și distracțiile publice, religia. Atunci de ce să renunțăm la evidenta probă de patriotism care este limba maternă?]

Fragmentul (12) evidențiază o perspectivă individuală și emancipatoare: este important ca indivizii să se poată exprima liber, iar această libertate este garantată de folosirea limbii materne. În mod similar, fragmentul (13) accentuează importanța unei limbi comune pentru comunicarea deschisă într-o societate și pentru răspîndirea cunoașterii: recursul la limba franceză ar atrage o ruptură de nedorit față de clasele medii și inferioare. Prin contrast, fragmentul (14) insistă asupra importanței pe care sentimentul identității îl poate avea în constituirea unei națiuni. Cu alte cuvinte, atît tematica romantică, cît și cea raționalistă pot fi prezente în discursul adepților mișcărilor naționaliste.

Totuşi, în dezvoltarea mișcărilor naţionale din secolul al XIX-lea, s-a insistat din ce în ce mai mult asupra naționalismului de sorginte romantică. Minoritățile care aspirau la independență și-au asumat în chip naiv o anumită identitate sau și-au construit una în mod deliberat, astfel încît statele-națiuni să poată dezvolta fățiş o identitate colectivă, lingvistică sau de altă natură. Aceste mecanisme sînt arhicunoscute în literatura asupra naționalismului (conform unor autori precum Hobsbawm, Anderson, Gellner, Smith). Pentru cercetarea de față, e crucial să observăm că naţionalismul romantic dezvăluie paradoxurile modelului cultural romantic pe care l-am identificat mai sus. Trecerea de la modelul romantic, așa cum a fost el prezentat anterior, la modelul naţionalist constituie așa-numita 'dialectică a Romantismului', conturată prin analogie cu 'dialectica Iluminismului', și care se referă la procesul oarecum natural prin care modelul romantic original se lasă subminat și devine contradictoriu în raport cu unele din premizele sale de început.

Paradoxul modelului naționalist de sorginte romantică este următorul. Pe pe de o parte, se pretinde recunoașterea diversității, a egalității în drepturi și a independenței politice pentru o anumită comunitate (lingvistică) în raport cu altele. Pe de altă parte, trebuie asumată o anumită omogenitate internă în cadrul comunității respective, pentru simplul motiv că, în logica romantică, cea care legitimează recunoașterea este identitatea colectivă. Dar identitatea ar trebui impusă sau construită, iar vocile dizidente ar trebui reduse la tăcere.

Prin urmare, modelul romantic este tot atît de supus dezvoltărilor contradictorii ca și modelul raționalist. În dezbaterea lingvistică, forma specifică de manifestare a poziției naţionaliste de inspirație romantică este grija față de puritatea limbii. Apărarea limbii comune împotriva influențelor străine (a împrumutului lexical, de fapt) este, în același timp, o apărare a identității culturale a poporului. În subminarea naționalistă a modelului romantic original, identitățile nu sînt doar exprimate, ci și permanentizate. Și legătura dintre purism şi naţionalism este binecunoscută, existînd o literatură bogată asupra purismului. Ceea ce doresc să evidențiez în această privință ține mai puțin de fenomen ca atare şi mai mult de înscrierea în tiparul general definitoriu pentru logica paradoxală a modelelor raționalist și romantic referitoare la variația lingvistică.

În rezumat, această logică paradoxală se întemeiază pe cîteva aspecte. În primul rînd, deși modelele de bază se opun unul altuia, ele se întîlnesc pe terenul noțiunii de naționalism. Deoarece modelul raționalist nu își poate concretiza cu uşurinţă pretențiile universaliste și întrucît modelul romantic nu își poate împlini cu uşurinţă tezele sale individualiste radicale, cele două modele află teren comun atunci cînd anumite grupuri de indivizi își reclamă identitatea și independența politică. În al doilea rînd, această întrepătrundere de modele nu elimină tensiunile ce există între ele, din moment ce istoria ultimelor două sute de ani e plină de exemple de conflicte între modelul raționalist de Staatsnationalismus (naționalism civic la nivelul statului-națiune) și modelul romantic de Volksnationalismus (naţionalism bazat pe identitate etnică sau culturală). În al treilea rînd, pe lîngă tensiunile dintre modelele de bază, trebuie să luăm în considerare 
și tensiunile din interiorul fiecărui model: modelul raționalist poate fi periclitat de discriminările 'dialecticii Iluminismului', iar premiza romantică de omogenitate internă poate, la fel de bine, avea consecințe opresive.

\subsection{Secolul al XX-lea și conştiinţa postmodernă}

Trăind în continuarea epocii națiunilor, trebuie să completăm tabloul transformărilor istorice ale modelelor culturale de variație lingvistică prin cartografierea schimbărilor lansate în dezbatere de ambianța postnaționalistă. Starea actuală poate fi cel mai bine caracterizată de două tendințe suprapuse: globalizarea și postmodernismul.

Globalizarea este un fenomen de natură economică și politică (în măsura în care importanța crescîndă a organizațiilor internaționale diminuează importanța de odinioară a statului-națiune). Dar ea este și de factură lingvistică: răspîndirea internaţională a limbii engleze aproape că împlinește vechiul vis raționalist al unei limbi universale.

Pe de altă parte, conștiințta postmodernă are două trăsături. Prima, așa-numita 'dispariție a narațiunilor fondatoare ${ }^{2}$, semnalează slăbirea vechilor tipare interpretative. Destul de multă suspiciune planează asupra modelului raționalist de progres lin și emancipator, precum și (sau mai ales) asupra modelului naționalist. Gîndirea postmodernă este conștiința de sine de la sfîrșitul secolului al XX-lea, în accord cu care progresul nu se produce automat, iar naţionalismul este periculos.

Această atitudine critică implică o a doua trăsătură: din moment ce vechile modele nu mai au tot atît de mult impact, este posibilă manifestarea de-ierarhizării și de-formalizării. Dacă, de pildă, ordinea ierarhică inițială a culturii înalte și culturii populare este respinsă pe motiv că face parte din vechile modele de interpretare, atunci cultura populară poate reclama egalitatea de drept față de cultura înaltă.

Aceste două trăsături sugerează că postmodernismul este, în mare măsură, o formă reînnoită a vechii atitudini romantice, dat fiind că reîmprospătează perspectiva critică, de natură 'contraculturală, referitoare la narațiunile oficiale, și reînvie apelul la diversitate.

Din punctul nostru de vedere, este interesant de observat dacă aceste schimbări conduc sau nu spre o transformare fundamentală a modelelor culturale întrebuințate pentru a discuta variația lingvistică. În fond, este vorba despre o creștere a interesului față de raporturile internaționale dintre limbi, în locul raporturilor naționale dintre varietățile unei limbi. Modelele originale de standardizare sînt esențialmente modele de normare a limbii literare în raport cu dialectele și cu celelalte varietăți ale aceleiași limbi. În epoca națiunilor, dezbaterea situa doar uneori limbile naționale în opoziție cu limbile minorităților, și numai în zilele noastre dezbaterea se axează asupra raporturilor internaţionale dintre diferite limbi, în speță raporturile dintre limba engleză, ca limbă globală, și limbile locale, amenințate cu dispariția.

Astfel, în măsura în care poziția limbii engleze globale devine subiect central de discuție, vechea opoziție dintre atitudinea raționalistă și cea romantică capătă un nou impuls. Am observat mai sus că afirmațiile lui Skutnabb-Kangas privind tratamentul minorităţilor lingvistice se situează într-un aşa-numit cadru 'romantic'. În același timp, nu este dificil să vedem ce formă ia tiparul de bază al argumentului raţionalist în concepția lui Skutnabb-Kangas.

Mai întîi, pentru a contracara identificarea culturii cu limba, raționalistul poate semnala cazurile în care aceeași limbă este, fără dificultate, împărtășită de diferite culturi, și, invers, cazurile în care aceeași cultură unește vorbitori de limbi diferite.

Mai apoi, la acuzația că răspîndirea internațională a limbii engleze provoacă discriminări, raționalistul ar putea sublinia efectele benefice de emancipare pe care le presupune cunoașterea acesteia. Dacă engleza este, într-adevăr, o cheie către comunicarea internațională (și, dacă, de fapt, învățarea limbii engleze este posibilă pentru oricine), atunci este doar de apreciat faptul că tot mai mulți oameni sînt capabili să comunice astfel.

${ }^{2}$ Concept propus de filosoful francez Jean François Lyotard (1924-1998), în lucrarea La condition postmoderne: rapport sur le savoir (1979) - (n.tr.). 
Dar, în același timp, dezbaterile actuale par să conducă spre dezvoltarea unui model bazat pe diferențierea funcțională a varietăţilor implicate-cu alte cuvinte, un model de tipul 'și/și' în loc de un model 'fie/fie'. Într-o discuție axată pe situația internaţională, începe să fie acceptată ideea că plurilingvismul este un fapt natural. Este interesant de observat că deplasarea către plurilingvism văzut ca o (aşa-zisă) sinteză dialectică a unor forțe opuse poate să decurgă atît din modelul raționalist cît și din cel romantic. Am văzut, în secțiunea precedentă, că deplasarea către naționalism s-a potrivit logicii ambelor modele de bază, dacă s-a luat în considerare problema 'nivelelor de relevanță. Sub acest aspect putem observa că, în chip asemănător, interesul recent acordat plurilingvismului se potrivește ambelor modele.

Pe de o parte, o soluție plurilingvistică pare să presupună un fel de distribuție funcțională: o limbă se folosește într-un ansamblu specific de împrejurări, și alta pentru un alt set de circumstanțe. $\mathrm{O}$ astfel de specializare contextuală diglosică sau poliglosică nu este incompatibilă cu modelul raționalist inițial. De fapt, modelul raționalist are la bază dorința de a asigura participare democratică maximă în ceea ce uneori numim 'arii secundare' ale vieții sociale, mai exact, domeniile publice de activitate precum educaţia universitară sau viața politică. În privința 'ariilor principale', începînd cu aspectele vieții private, existența unor varietăți lingvistice locale mai puțin uniforme nu intră în contradicție cu fundamentul ideologic al modelului.

Pe de altă parte, turnura postmodernă a modelului romantic creează o nouă atitudine privind problema identității personale. De fapt, se spune adesea, că una din mărcile mentalității postmoderne este fragmentarea identității. Indivizii nu mai sînt caracterizați de o singură identitate, ci de identităţi diferite, în continuă transformare, de natură profesională, socială, etnică și culturală. În consecință, diverse limbi ar putea, urmînd logica originară 'expresivă' a atitudinii romantice, să exprime această fragmentare (sau, mai degrabă, multiplicare) a identităților.

Deși plurilingvismul pare să ofere o posibilă sinteză a modelelor iniţiale, soluția multilinguală nu poate, totuși, să elimine total tensiunile. Așa cum convergența naționalistă a modelelor din secolul al XIXlea a produs o tensiune între statele națiuni și minorități, tot astfel convergența plurilingvistică provoacă tensiuni legate de distribuția funcțională și situațională exactă a varietăţilor lingvistice. Un exemplu simplu ar fi reforma educației universitare în Europa. Impunerea unui sistem uniform de Licenţă/Masterat are, printre altele, scopul de a stimula mobilitatea studenților, ceea ce, la rîndul său, duce la presiunea de a introduce limba engleză ca limbă de educație, cel puțin la nivel de masterat. Totuși, este evident că mulți sînt reticenți în a accepta o asemenea limitare funcțională în folosirea limbii naționale materne.

De asemenea, tensiunile interne din cadrul fiecărui model continuă să se acumuleze. De exemplu, cei care apreciază introducerea englezei internaționale drept o şansă acordată tuturor de a participa în mod egal la cultura globală pot, cu ușurință, să ignore faptul că accesul la învățarea limbii engleze nu este egal pentru toți. Iar partizanii diversității lingvistice pot trece ușor cu vederea faptul că oamenii pe care intenționează să îi apere preferă adesea oportunitățile educaționale și profesionale oferite prin intermediul limbilor străine (cum este, de pildă, cazul majorității țărilor africane, foste colonii britanice).

Așadar, situația actuală se poate rezuma astfel încît să corespundă concluziilor de la sfîrșitul \$3.2. Pe de o parte, așa cum naționalismul a favorizat fuziunea modelului raționalist cu cel romantic, plurilingvismul poate fi un punct de convergență dintre manifestările post-naționaliste ale modelelor. Pe de altă parte, așa cum naționalismul nu a abolit nici tensiunile primare dintre modele, nici tensiunile interne ale modelelor, nici plurilingvismul nu elimină tensiunea dintre atitudinea raționalistă de a considera limba engleză, în plan global, ca pe o oportunitate comunicativă și educativă și atitudinea romantică de a o considera ca pe o amenințare la adresa diversității și a identității locale. Dar, în același timp, nu trebuie să uităm faptul că plurilingvismul se află abia la început, iar pozițiile din această dezbatere nu s-au cristalizat la fel de bine ca cele din vechea dezbatere asupra naționalismului.

\subsection{Rezumarea modelelor și a transformărilor lor}

Acum putem identifica tiparul reieșit din discuția purtată în paginile precedente. Luînd în considerare climatul filosofic și cultural al secolului al XVIII-lea, am distins două modele principale de standardizare 
lingvistică: modelul raționalist și cel romantic. Pornind de la o concepție comunicativă asupra limbajului verbal, primul model accentuează funcția emancipativă a limbii comune ca instrument de participare politică și educativă. Pe de altă parte, pornind de la o concepție expresivă asupra limbajului verbal, modelul romantic evidențiază maniera în care impunerea unei limbi literare poate defavoriza anumite identități culturale specifice. Așadar, se poate observa existența unei tensiuni între cele două modele în asemenea măsură încît unul poate deveni opusul celuilalt. Această tensiune este subliniată de 'dialectica Iluminismului', mecanismul prin care implementarea modelului raționalist poate da naștere opusului său.

De-a lungul transformărilor succesive suferite de aceste modele în decursul secolelor al XIX-lea și al XX-lea, nu am identificat numai variante ale celor două modele de bază, ci am și indicat tensiunile dintre ele reapărute în diferite ipostaze. Acestea sînt ilustrate în Tabela 2.

\begin{tabular}{|c|c|c|c|}
\hline & $\begin{array}{l}\text { SECOLUL AL XVIII-LEA: } \\
\text { modelele de bază }\end{array}$ & $\begin{array}{l}\text { SECOLUL AL IX-LEA: } \\
\text { naționalism }\end{array}$ & $\begin{array}{l}\text { SFÎRȘITUL SECOLULUI AL } \\
\text { XX-LEA: postmodernism }\end{array}$ \\
\hline $\begin{array}{l}\text { poziția } \\
\text { raționalistă: }\end{array}$ & $\begin{array}{l}\text { limba comună văzută ca } \\
\text { instrument de participare } \\
\text { politică și educativă }\end{array}$ & $\begin{array}{l}\text { națiunea văzută ca nucleu } \\
\text { al democrației liberale }\end{array}$ & $\begin{array}{l}\text { limba engleză internațio- } \\
\text { nală văzută ca oportunitate } \\
\text { / plurilingvismul } \\
\text { considerat ca specializare } \\
\text { funcțională }\end{array}$ \\
\hline $\begin{array}{l}\text { poziția } \\
\text { romantică: }\end{array}$ & $\begin{array}{l}\text { limba literară văzută ca } \\
\text { mijloc de defavorizare a } \\
\text { identităților particulare }\end{array}$ & $\begin{array}{l}\text { națiunea văzută ca nucleu } \\
\text { al identității culturale și } \\
\text { etnice }\end{array}$ & $\begin{array}{l}\text { limba engleză internațio- } \\
\text { nală văzută ca amenințare / } \\
\text { plurilingvismul considerat } \\
\text { ca expresie a identităților } \\
\text { fragmentate, postmoderne }\end{array}$ \\
\hline $\begin{array}{l}\text { tensiunea } \\
\text { dintre cele } \\
\text { două poziții: }\end{array}$ & $\begin{array}{l}\text { opoziția dintre cele două } \\
\text { modele este amplificată de } \\
\text { 'dialectica Iluminismului' }\end{array}$ & $\begin{array}{l}\text { conflictul dintre statele- } \\
\text { națiuni și grupurile etnice } \\
\text { / culturale }\end{array}$ & $\begin{array}{l}\text { ce formă exactă ia } \\
\text { specializarea funcțională? }\end{array}$ \\
\hline
\end{tabular}

Tabela 2: Cultural models of standardization and their historical transformations

În secolul al XIX-lea, se realizează convergența parțială a modelelor în jurul noțiunii de naționalism. De fapt, ambele modele sînt problematice în privința nivelului de relevanță: cît de amplă ar trebui să fie comunitatea de vorbitori vizată în modelul raționalist? Și cît de particulară ar trebui să fie identitatea vizată în modelul romantic? În loc să ia forma extremelor universaliste sau individualiste, interpretarea naționalistă a modelelor preferă o cale de mijloc. Din perspectivă raționalistă, națiunea se definește prin nivelul la care participarea democratică este garantată. Din perspectivă romantică, identitatea exprimată este cea a colectivității, a comunității care se constituie ca națiune. Aceste două forme de naționalism sînt, bineînțeles, foarte cunoscute: naționalismul liberal (naționalismul civic, Staatsnationalismus) care consideră națiunea ca bază a democrației liberale, și naționalismul romantic (naţionalismul identitar, Volksnationalismus) care consideră națiunea ca nucleu de identitate culturală și etnică. Tensiunile dintre cele două sînt tot atît de cunoscute: statul-națiune liberal nu trebuie să coincidă cu un singur grup cultural sau etnic, iar aceste grupuri ar putea sa reclame statut de națiune independentă. E de la sine înțeles că diferențele lingvistice pot avea un rol crucial în definirea grupurilor implicate. În plus, nu trebuie uitat că un model politic federal constituie un compromis destul de frecvent pentru a aplana tensiunile dintre pretențiile statelor-națiuni şi cele ale grupurilor naționaliste.

Sfîrșitul secolului al XX-lea este caracterizat de un proces de globalizare politică și economică care îşi are echivalentul atitudinal într-o perspectivă postmodernă asupra lumii, şi echivalentul lingvistic în răspîndirea globală a limbii engleze. Prin urmare, dezbaterea se deplasează către poziția limbii engleze în raport cu limbile locale, și aflate în potențial pericol. Deși se pare că procesul nu a atins încă punctul culminant, dezbaterea pare să ị̂i găsească un nou reper în conceptul de plurilingvism văzut ca posibilitate 
de reconciliere între tabere. Așa cum naționalismul secolului al XIX-lea a urmat în mod firesc modelelor inițiale (prin problema nivelelor de relevanță), plurilingvismul implică o specializare funcțională acceptabilă a diferitelor limbi; din moment ce limba este un mijloc de comunicare, situații comunicative diferite solicită uzul unor limbi diferite. În cazul modelului romantic, plurilingvismul se leagă de identitatea fragmentată a individului postmodern; dacă presupunem că oamenii ar putea avea identităţi diferite, atunci ei ar putea folosi diferite limbi pentru a-și exprima aceste identități. Totuşi, deplasarea către plurilingvism nu elimină tensiunea: specializarea funcțională exactă a limbilor implicate rămîne sursă de conflict.

\section{Concretizarea modelelor}

În cercetarea lingvistică, modelele raționalist, romantic, naționalist și postmodern pe care le-am identificat, pot fi, în esență, valorificate în două feluri. Pe de o parte, ele pot fi utilizate ca bază pentru analiza oricărui discurs referitor la problematica standardizării. Mai sus am oferit deja cîteva exemple care arată cum pot fi folosite modelele culturale în analiza logicii dezbaterilor privind standardizarea. În general, o astfel de analiză identifică componentele discursive prin care se exprimă, se amendează sau se contraargumentează elemente ale modelelor de bază. Am putea merge mai departe pentru a identifica tipare ale afirmațiilor și replicilor care ar fi de așteptat în acest tip de dezbatere, dar nu am intenția să dezvolt în mod sistematic această problemă în prezentul studiu.

Pe de altă parte, atitudinile faţă de limbă bazate pe unul sau altul dintre modele pot influența dezvoltarea actuală a mecanismelor de standardizare. În cele ce urmează, voi avea în vedere acest al doilea aspect, pe baza cercetării pe care am desfăşurat-o cu echipa mea asupra variației interne a limbii olandeze contemporane. În $\$ 4.1$ voi rezuma cele mai importante rezultate obținute (această secțiune poate fi sărită de cititorii mai puțin interesați de detaliile tehnice ale proiectului). În secțiunea $\$ 4.2$, voi discuta maniera în care modelele culturale de standardizare pot influența rezultatele finale ale proiectului.

\subsection{Olandeza contemporană ca limbă pluricentrică}

Limba olandeză are două varietăți principale: olandeza vorbită în Olanda și olandeza vorbită în Flandra, Belgia (denumită, uneori, și 'flamandă). Starea limbii literare din cele două țări este întrucîtva diferită. În Flandra, procesul de standardizare care a început, la fel ca în majoritatea țărilor europene, în modernitatea timpurie a fost încetinit din cauza separării politice a Flandrei de Olanda, în timpul Războiului de Optzeci de Ani. Limba olandeză literară s-a dezvoltat în Olanda în decursul secolului al XVII-lea, dar, cum Flandra a fost separată politic de Olanda, rămînînd sub ocupație străină (spaniolă sau austriacă), flamanda nu a fost legată de acest proces de standardizare. De fapt, franceza a fost din ce în ce mai mult folosită ca limbă de guvernămînt și de cultură, practică accelerată de formarea statului belgian, în 1830. Astfel, olandeza a supraviețuit mai ales ca formă a unei varietăți dialectale flamande.

Cu toate acestea, olandeza din Flandra și-a recîștigat poziția de limbă literară (limbă a educației, a guvernării și a culturii înalte) ca urmare a luptei politice și sociale pentru emanciparea Flandrei și a populației vorbitoare de flamandă din Belgia. Acest proces a început, cu ezitări, la sfîrșitul secolului al XIX-lea, ca mișcare tipic romantică, a luat avînt în prima jumătate a secolului al XX-lea și a făcut un salt important după Cel de-al Doilea Război Mondial și în perioada înfloritoare a anilor şaizeci. Majoritatea lingviștilor este, totuși, de acord cu faptul că procesul de standardizare nu s-a încheiat, sau, cel puțin, nu a atins același nivel de standardizare ca neerlandeza.

Cea de-a doua observație constituie punctul de plecare al cercetării noastre: putem cuantifica relația dintre olandeza belgiană și cea neerlandeză (în ceea ce privește stratificarea internă a ambelor varietăți)? Putem estima cît de apropiate sau de îndepărtate sînt, una față de cealaltă, cele două varietăți ale limbii olandeze? Mai exact, ținînd cont că cercetarea noastră este axată, în principal, asupra variației lexicale, cum se poate cuantifica convergența sau divergența lexicală dintre două varietăți lingvistice? În Geeraerts et al. (1999) a fost conceput un instrument de măsurare a suprapunerii lexicale, bazat pe noțiunile de profil onomasiologic și uniformitate. 
Profilul onomasiologic al unei noțiuni dintr-o anumită sursă constă într-un set de denumiri sinonimice ale aceleiași noțiuni, diferențiate conform unor frecvențe relative. Tabela 3 conține profilurile onomasiologice pentru overhemd 'cămașă' în baza de date belgiană și olandeză din 1990.

\begin{tabular}{lcc} 
& Olandeza belgiană 1990 (B90) & Neerlandeza 1990 (N90) \\
\hline hemd & $31 \%$ & $17 \%$ \\
overhemd & $69 \%$ & $46 \%$ \\
shirt & $0 \%$ & $37 \%$
\end{tabular}

Tabela 3: Profiluri onomasiologice pentru cămaşă

Uniformitatea este unitatea de măsură a corespondenței dintre două profiluri onomasiologice. Uniformitatea este estimată pornindu-se de la ideea că o normă lingvistică comună atrage un comportament lingvistic uniform. In extremis, se ajunge la uniformitate lexicală în denumirea unei noțiuni atunci cînd în două varietăți lingvistice există aceeași denumire pentru respectiva noțiune, sau cînd în cele două varietăți există mai multe denumiri cu frecvențe identice. Totuși, corespondențele parțiale, precum cele prezentate în Tabela 3, sînt mult mai frecvente decît exemplele „ideale” de uniformitate menționate mai sus. Am putea, spre exemplu, să presupunem că, în loc de procente, frecvențele relative din Tabela 3 reprezintă 100 de situații denominative reale în fiecare din cele două profiluri. Suprapunerea parțială dintre profilurile incluse în Tabela 3 este cuantificată prin numărarea situațiilor denominative pentru care există corespondențe în celălalt profil. În scenariul ideal conturat anterior, fiecare din cele 100 de denominații dintr-un profil are corespondență în celălalt, ceea ce duce la o uniformitate maximală de $100 \%$. Cu toate acestea, în Tabela 3, 14 ocurențe ale cuvîntului hemd din B90 nu se regăsesc în N90, 23 de situații de folosire a lui overhemd în olandeza belgiană nu au nici un corespondent în neerlandeză și, în plus, nu există nici o corespondență în olandeza belgiană pentru 37 de ocurențe ale lui neerlandezului shirt. Din totalul de 200 de denominații din cele două profiluri, numai în $200-(14+23+37)=126$ de situații există corespondențe în celălalt profil, reprezentînd o uniformitate de $126 / 2=63 \%$. Dacă dorim să avem o evaluare cantitativă, trebuie să observăm faptul că acest procent este egal cu cea mai mică frecvență relativă pentru fiecare termen alternativ, adică $17+46+0=63 \%$.

Cînd se analizează mai multe noțiuni, indicele de uniformitate $U$ se definește ca media indicilor de uniformitate ai noțiunilor luate separat, în timp ce indicele de uniformitate U' se definește ca medie ponderată, în care frecvența relativă a fiecăreia din noțiunile analizate este luată în considerare. În cazul de față, ne vom axa exclusiv pe media ponderată U', în care noțiunile cu frecvență mare au un impact mai evident asupra uniformităţii de ansamblu.

Baza empirică a proiectului de cercetare a constat în culegerea a 40000 de instanțe de uz lingvistic. Am adunat diversele denumiri (și frecvențele lor) folosite pentru a desemna treizeci de noțiuni, cincisprezece din domeniul terminologic al vestimentației și cincisprezece din domeniul fotbalului. Baza de date rezultată ne permite, de exemplu, să estimăm în ce proporție sînt prezenți în surse belgiene și olandeze termenul buitenspel 'offsaid' și împrumutul offsaid, pentru noțiunea OFFSAID; în cazul noțiunii JURK 'rochie', putem aprecia dacă alegerile lexicale indică o preferință pentru jurk, jupon, sau kleed. Nucleul materialului lingvistic analizat a fost extras din reviste și ziare din anul 1990.

Acest nucleu a fost extins în două maniere. Mai întîi, am colectat material similar pentru anii 1950 și 1970, fapt ce ne-a permis să realizăm o analiză în timp real a proceselor de convergență și divergență lexicală. Apoi, a fost luată în considerare stratificarea uzului lingvistic. Între varianta literară a limbii şi cea dialectală există mai multe straturi în care pot apărea, simultan, diferențe de registru cu specializare geografică crescută. În cazul cercetării legăturii dintre olandeza belgiană și cea neerlandeză, aceste straturi-adică variantele regionale informale ale limbii literare-sînt deosebit de relevante și e de așteptat ca diferențele lingvistice dintre Belgia și Olanda să crească la acest nivel regiolectal. Acest nivel intermediar între dialect și limba literară scrisă a fost reprezentat de termenii referitori la vestimentație pe care i-am adunat de pe etichetele din vitrinele magazinelor din două orașe belgiene (Leuven și Kortrijk) și din două 
orașe olandeze (Leiden și Maastricht). Publicul-țintă al acestei forme de comunicare este mai restrîns decît publicul național sau binațional vizat de revistele din care am selectat nucleul materialului. Pe de altă parte, faptul că am avut de-a face cu un limbaj scris într-o situație semi-formală ne-a îndepărtat de polul pur dialectal al continuumului stratificaţional.

Care ar fi, conform acestei baze de date, așteptările privind raporturile dintre diferitele varietăţi lingvistice? În ceea ce privește statutul și evoluția olandezei belgiene, două ipoteze fără echivoc pot fi desprinse din studiile de specialitate. Prima se referă la posibilitatea unei convergențe diacronice între olandeza belgiană și neerlandeză. Procesul de standardizare din Flandra se caracterizează printr-o orientare normativă explicită spre olandeza belgiană: standardizarea olandezei belgiene a constat în adoptarea limbii olandeze literare din Olanda. Mai mult decît atît, se consideră că procesul neterminat de standardizare a olandezei belgiene se manifestă printr-o distanță sincronică mai mare între varianta regională și cea națională din Belgia decît din Olanda și chiar și pentru un public neavizat este evident că diferențele dintre registrele regionale și supraregionale sînt mai mari în Belgia decît în Olanda.

$\begin{array}{ll}\text { B50 / N50: } & 69,84 \\ \text { B70 / N70: } & 74,59 \\ \text { B90 / N90: } & 81,70 \\ \text { B90 / B } \\ \text { N90: } & 45,90 \\ \text { N90 / N } \text { Nw }_{\text {sw }} \text { : } & 67,75\end{array}$

Tabela 4: Valorile comparative ale indicelui U’ din Belgia și Olanda (1950-1970-1990) și datele comparative preluate din reviste și ziare și din vitrinele magazinelor locale.

Ipotezele diacronice și sincronice pot deveni operaționale din perspectiva valorilor uniformităţii definite mai sus. Din punct de vedere diacronic, convergența și divergența pot fi cuantificate drept uniformitate crescătoare sau descrescătoare. Din punct de vedere sincronic, distanța crescută dintre varianta națională și cea locală pe care ne așteptăm să o găsim în olandeza belgiană se va manifesta printr-o uniformitate mai scăzută în materialul cules din revistele și etichetele scrise în olandeza belgiană decît în cel cules din sursele neerlandeze.

Tabela 4 conține rezultatele relevante. B50 înseamnă 'date din olandeza belgiană din 1950', N50 înseamnă 'date din neerlandeză din 1950, B $_{\mathrm{sw}} 90$ se referă la materialele colectate din vitrinele magazinelor din Belgia, spre deosebire de B90 care se referă la datele adunate din reviste și ziare. Datele din Tabela 4 confirmă fără echivoc ipoteza diacronică și pe cea sincronică. Din punct de vedere diacronic, creșterea în uniformitate între olandeza belgiană și cea neerlandeză sugerează o convergență lexicală evidentă a celor două varietăți:

$\begin{array}{lll}\mathrm{U}^{\prime}(\mathrm{B} 50, \mathrm{~N} 50) & <\mathrm{U}^{\prime}(\mathrm{B} 70, \mathrm{~N} 70) & <\mathrm{U}^{\prime}(\mathrm{B} 90, \mathrm{~N} 90) \\ 69.84 & <74.59 & <\end{array}$

Din punct de vedere sincronic, standardizarea întîrziată sau neîncheiată a olandezei belgiene se manifestă printr-o uniformitate evident mai scăzută între datele belgiene culese din reviste și cele culese din vitrinele magazinelor decît în datele similare din materialul neerlandez:

$\begin{array}{ll}\mathrm{U}^{\prime}\left(\mathrm{B} 90, \mathrm{~B}_{\mathrm{sw}} 90\right) & <\mathrm{U}^{\prime}\left(\mathrm{N} 90, \mathrm{~N}_{\mathrm{sw}} 90\right) \\ 45.90 & <67.75\end{array}$

\subsection{Modele culturale și evoluția olandezei belgiene}

Situația generală a diferitelor varietăţi ale limbii olandeze este rezumată în Figura 1. Partea din stînga a figurii reprezintă neerlandeza în timp ce partea din dreapta reprezintă olandeza belgiană ('flamanda'). Dimensiunea verticală reprezintă stratificarea internă a ambelor varietăți naţionale și reflectă distincția 
dintre registrul standard, familiar (colocvial) și cel local. Distanțele din schemă reprezintă distanțele lingvistice. În partea superioară, ambele varietăți naționale sînt aproape una de cealaltă, însă distanțele cresc în registrele inferioare. În mod semnificativ, olandeza belgiană (flamanda) colocvială este mult mai îndepărtată de registrul standard în Belgia decît este neerlandeza colocvială de cea formală. Așadar, cum va evolua olandeza belgiană?

În esență, există trei posibilități. Prima ar sugera faptul că această stare este doar etapă trecătoare spre convergență și standardizare. Am văzut că există dovezi care să sprijine ideea unei evoluții convergente, cel puțin în stratul superior al limbii, și putem presupune că această evoluție va continua și în straturile inferioare. În acest caz, flamanda colocvială va atinge, în figura de mai jos, un nivel probabil similar cu cel al neerlandezei. A doua ipoteză se referă la inversarea procesului de convergență. Trăsături tipice ale flamandei colocviale ar putea fi încorporate în standardul folosit în Belgia, iar acest proces de informalizare a limbii literare ar putea duce la o creștere a distanței de nivel superior între olandeza belgiană și cea neerlandeză. A treia ipoteză implică menținerea unei situații stabile.

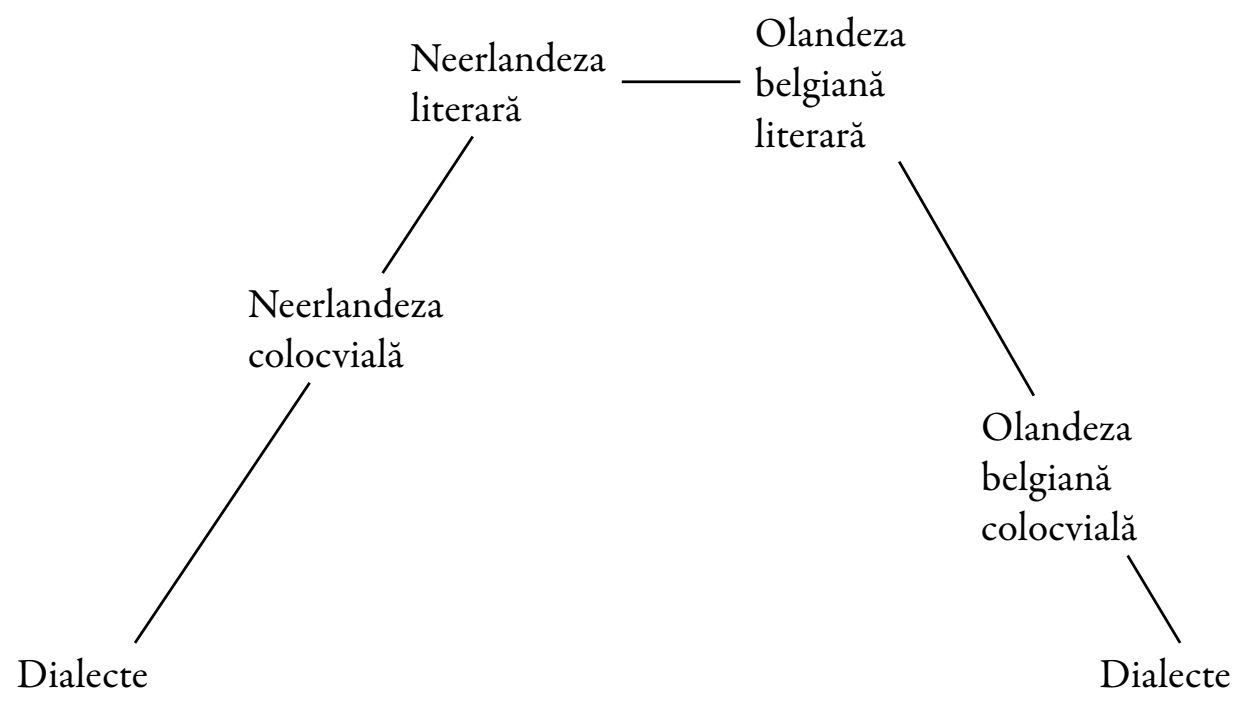

Figura 1: Stratificarea olandezei contemporane

De fapt, ceea ce aş dori să sugerez este că o alegere concretă dintre cele trei posibilități logice ar putea fi, măcar în parte, determinată de măsura în care cele trei modele de standardizare sînt răspîndite în comunitatea lingvistică.

Prima posibilitate (cea în care flamanda colocvială se apropie de nivelul superior, cel literar) ar primi cel mai mare imbold din partea unei atitudini raționaliste față de procesele de standardizare. O tendință crescîndă de a participa în aceste activități care sînt asociate în special cu utilizarea limbii literare ar merge mînă în mînă cu o răspîndire a limbii literare în ipostaza sa actuală. Este mai puțin clar, însă, dacă acest proces ar implica și o convergență a registrului superior cu neerlandeza: dincolo de aspectul în general universalist al atitudinii raționaliste, adică tendința de a lărgi sfera comunicativă a limbii, motivația funcțională pentru o asemenea convergență ar putea părea relativ insuficientă.

Trebuie să constatăm că un proces de convergență continuă ar putea fi, de asemenea, provocat de o atitudine naționalistă, dacă flamanzii și olandezii se simt ca un popor supra-național, uniţi de o limbă comună, dincolo de hotarele dintre Belgia și Olanda. Totuși, deși există un curent minor care susține o astfel de uniune 'etnică a Olandei și a Flandrei, acesta nu are un rol important în conștiința majorității. Sentimentele dintre olandezi și flamanzi sînt mai degrabă de competiție și ușoară animozitate decît de solidaritate etnică și lingvistică.

Cea de-a doua posibilitate (o uniformitate internă crescîndă în olandeza belgiană, dobîndită printr-o informalizare a registrului cel mai înalt) ține de modelul naţionalist. În Belgia, Flandra a atins emanciparea politică, iar acest fapt s-ar putea oglindi într-o independență lingvistică crescută, cu alte cuvinte, în 
dezvoltarea unei norme independente a limbii literare care se diferențiază din ce în ce mai mult față de modelul neerlandez ce a constituit punctul de referință inițial în procesul de standardizare. Dacă modelul naţionalist are întîietate și dacă este orientat doar către Flandra și nu către o uniune 'etnică' între Flandra și Olanda, vorbitorii de flamandă ar putea dezvolta o preferință mai accentuată pentru formele lingvistice indigene întîlnite la nivel familiar decît pentru cele de import, din registrele superioare.

A treia posibilitate (cea de status quo) are o alură romantică și postmodernă, dacă ținem cont că atitudinea romantică în forma ei pură implică atitudini anti-instituționale. Interesul romanticilor față de standardizare (dacă nu este ridicată la nivel de naționalism) este în fond îndoielnic: standardizarea este considerată un pericol pentru diversitate, în general, și pentru identitatea locală și individuală, în particular. Prin distanțarea de standardul oficial, romanticul are mai multe opțiuni: el poate să pledeze pentru diversitate (acceptarea tuturor varietăților ca fiind egale), ori poate să încerce să își impună propria sa limbă ca standard (opțiunea naționalistă), însă, la fel de bine, își poate menține distanța, acceptînd că există o limbă folosită în împrejurări oficiale cu care nu se identifică și un limbaj familiar cu care se simte confortabil și care este suficient de îndepărtat de limba oficială pentru a fi perceput ca o expresie a identităţii sale 'reale'.

Există cumva indicii care să ateste că Flandra ar putea avea o mentalitate favorabilă unei asemenea forme stabile de diglosie? Imaginea populară de sine ar putea să sprijine o asemenea ipoteză. Flandra se percepe ca națiune ușor anarhistă, în sensul că are o încredere foarte scăzută în autoritățile oficiale, și că nu ia foarte în serios legile și regulamentele. De exemplu, evaziunea fiscală este adesea descrisă ca un sport național. De asemenea, rațiuni istorice sînt adesea invocate pentru a explica această mentalitate. Așa cum am arătat anterior, istoria Flandrei este marcată de dominația străină, ceea ce, se pare, a creat o mentalitate caracterizată de distanțarea critică față de tot ceea ce înseamnă autoritate oficială. Tendințele postmoderne de informalizare și de-ierarhizare au întărit, la rîndul lor, această atitudine. Așadar, am putea oare afirma că o astfel mentalitate susţine o atitudine romantică diglosică în privința chestiunilor de natură lingvistică? Această ipoteză este destul de fascinantă pentru a garanta ulterioare studii empirice serioase asupra mentalității flamanzilor și a istoriei lor culturale.

De fapt, nu pot face nici un fel de predicții despre o posibilă evoluție a evenimentelor în Flandra. Această evoluție va fi determinată nu doar de modelele de atitudine menționate anterior și nu am încă date privind aceste atitudini care să determine forța uneia sau alteia dintre posibilități. Totuși, ceea ce am încercat să arăt este că se pot analiza mecanismele de standardizare din punctul de vedere al modelelor culturale identificate în prima parte a lucrării. Modelele culturale de standardizare sînt reale nu doar în măsura în care ele modelează dezbaterea publică, ci şi prin felul în care ele se plasează la baza atitudinilor lingvistice ale vorbitorilor unei limbi.

\section{Concluzii}

În această lucrare am încercat să ating cîteva obiective. În primul rînd, am arătat că maniera în care gîndim despre probleme referitoare la variația lingvistică și la standardizarea lingvistică poate fi redusă, cel mai adesea, la două modele culturale esențiale și antitetice: unul raționalist și unul romantic.

În al doilea rînd, am sugerat că aceste modele îşi au originea în secolul al optsprezecelea și au suferit mai multe transformări pe parcursul a două veacuri. Mai concret, în secolul al nouăsprezecelea, am asistat la dezvoltarea unui model naționalist foarte influent care a combinat elemente din cele două modele de bază, iar spre sfirșitul secolului al douăzecilea am fost martorii unei turnuri către probleme privind globalizarea și statutul internaţional al limbii engleze. În fiecare din aceste etape, modelele au manifestat tendinţă spre convergență, însă, în acelaşi timp, tensiunile au persistat, atît ca tensiuni între modele cît și ca tensiuni în interiorul fiecărui model.

În cele din urmă, am încercat să demonstrez că modelele în chestiune nu pot fi valorificate doar în chip discursiv-analitic, pentru a cerceta argumentații și dezbateri, ci și pentru că ele pot modela atitudinile față de limbă ale comunităților de vorbitori. Dacă manifestarea lor este reală, atunci ele nu se modelează doar 
felul în care oamenii vorbesc despre standardizare, ci și felul în care ei acționează.

Fiecare punct poate fi dezvoltat. Identificarea modelelor poate fi extinsă către crearea unei hărți sistematice a dezbaterilor privind standardizarea, prin înregistrarea tiparelor recurente de aserțiuni și răspunsuri pe această temă. Schița istorică poate fi dezvoltată într-o analiză istorică sintetică a mecanismelor de standardizare, a dezbaterilor privind standardizarea și a relației lor cu teoria lingvistică. Iar presupusa relație dintre modele și atitudini lingvistice ar putea conduce către studiul empiric al atitudinilor. Totuși, toate aceste direcții de dezvoltare a analizei ar trebui să aibă același scop, o mai bună înțelegere a logicii care stă la baza dezbaterilor referitoare la standardizare.

\section{Bibliography}

Barère, Bertrand (1975). Rapport du Comité de Salut Public sur les idiomes, în Certeau, M. .de, Julia, D. \& Revel, J. (eds.), Une politique de la langue: la Révolution française et les Patois, p. 291-299, Éditions Gallimard, Paris. Ediție princeps 1794.

Blommaert, J. \& Bulcaen, C. (eds.) (1997). Political Linguistics, John Benjamins, Amsterdam / Philadelphia, .

Burke, L., Crowley, T. \& Girvin, A. (eds.) (2002). The Routledge Language and Cultural Theory Reader, Routledge, London / New York.

Condillac, E. B.de (1973). Essai surl'Origines des Sciences humaines, Porset, Ch. (ed.), Galilée, Auvers-sur-Oise. Ediție princeps 1746.

Deprez, K. \& Vos, L. (eds.) (1998). Nationalism in Belgium: Shifting Identities, Macmillan, Basingstoke.

van Dijk, T. A. (1998). Ideology: A Multidisciplinary Approach, Sage, London, CrossRef.

Dirven, R., Hawkins, B. \& Sandikcioglu, E. (eds.) (2001a). Language and Ideology, I. Theoretical Cognitive Approaches, John Benjamins, Amsterdam / Philadelphia, CrossRef.

Dirven, R., Frank, R. \& Ilie, C. (eds.) (2001b). Language and Ideology, II. Descriptive Cognitive Approaches, John Benjamins, Amsterdam / Philadelphia, CrossRef.

Geeraerts, Dirk (1997). Diachronic Prototype Semantics, Clarendon Press, Oxford.

Geeraerts, D., Grondelaers, S. \& Bakema, P. (1994). The Structure of Lexical Variation. Meaning, Naming and Context, Mouton de Gruyter, Berlin / New York, .

Geeraerts, D., Grondelaers, S. \& Speelman, D. (1999). Convergentie en Divergentie in de Nederlandse Woordenschat. Een Onderzoek naar Kleding - en Voetbaltermen, Meertens Instituut, Amsterdam.

Grégoire, H.-B. (1975). Rapport sur la nécessité et les moyens d'anéantir les patois et d'universaliser l'usage de la langue française, în Certeau, M. de, Julia, D. \& Revel, J. (eds.), Une politique de la langue: la Révolution française et les Patois, p. 300-317, Éditions Gallimard, Paris. Ediţie princeps 1794.

Herder, J.G. (1978). Abhandlung über den Ursprung der Sprache, Wolfgang Pross (editor), Hanser, München. Ediție princeps 1772.

Holland, D. \& Quinn, N. (eds.) (1987). Cultural Models in Language and Thought, Cambridge University Press, Cambridge, CrossRef.

Horkheimer, M. \& Adorno, Th. W. (1947). Dialektik der Aufklärung, Querido, Amsterdam.

Joseph, J. \& Taylor, T. (eds.) (1990). Ideologies of Language, Routledge, London.

Lakoff, G. (1987). Women, Fire, and Dangerous Things. What Categories Reveal about the Mind, University of Chicago Press, Chicago, IL.

Lakoff, G. (1996). Moral Politics. What Conservatives Know and Liberals Don't, University of Chicago Press, Chicago, IL.

Palmer, G. (1996). Towards a Theory of Cultural Linguistics, University of Texas Press, Austin.

Reddy, M. (1979). The conduit metaphor - a case of frame conflict in our language about language, în Ortony, A. (ed.), Metaphor and Thought, Cambridge University Press, Cambridge, p. 284-384, .

Sapir, E. (1907). Herder's Ursprung der Sprache, în „Modern Philology”, nr. 5, p. 109-142, CrossRef. Re-publicat în „Historiographia Linguistica", nr. 11, p. 355-388 [1984], CrossRef.

Schiffman, H. (1996). Linguistic Culture and Language Policy, Routledge, London.

Skutnabb-Kangas, T. (2000). Linguistic Genocide in Education - or Worldwide Diversity and Human Rights?, Lawrence Erlbaum, Mahwah, NJ.

Wodak, R. \& Meyer, M. (eds.) (2001). Methods of Critical Discourse Analysis, Sage, London, CrossRef.

Woolard, K., Schieffelin, B. \& Kroskrity, P. (1998). Language Ideologies: Practice and Theory, Oxford University Press, Oxford.

Verlooy, J. B. C. (1979). Verhandeling op d'Onacht der Moederlyke Tael in de Nederlanden. Smeyers, Jozef and Van den Broeck, Jan (eds.), Martinus Nijhoff, Den Haag. Ediție de referință 1788. 